\title{
Need For Life Skills Education among Tribal and Non Tribal Students
}

\author{
Ankit Patel*
}

\section{ABSTRACT}

The academic achievement is correlates of Psychological variables. This research work was conducted on a sample of 350 tribal and 350 non-tribal students studying in secondary schools in PANCHMAHALS district with a view to finding out the effect of the intelligence and academic motivation on their academic achievement of the pupils in tribal secondary schools in Gujarat, India. The sample was collected from the students of non-government high schools of tribal area district who significantly differ in their intelligence and academic motivation. Desai's verbal-non verbal group test of intelligence was administrated to the students. Academic motivation test was developed by researcher and administrated to the students. The students' academic achievement tool is last preliminary examination score in March, 2011. The mean value analysis of significance of the mean difference and the values were calculated, other calculated is mean value analysis of variable and F-test. The findings show that there is no significant difference in the IQ and academic motivation of standard: X students in the secondary schools of tribal area of the PANCHMAHALS district, Gujarat-India.

Keywords: Life Skill Education, Tribal and Non Tribal Students

\section{REVIEW OF LITERATURE:}

The marginalized, by definition and logic and irrespective of faith, form or culture are smaller in number than the dominant (or mainstream) social groups. Indian society is marked by age-old tensions between marginalized groups, castes, tribes, and multiple social layers stemming from a spaghetti bowl of linguistic, racial and religious groups. People displaced by factors such as natural disasters, man-made political events (e.g. wars), economic changes, inconsistency in patterns of livelihood support, have continuously added to swelling numbers of these marginalized communities.

*MA, Clinical Psychology, Dept. of Psychology, Sardar Patel University, Vidhyanagar GujIndia

(C) 2014 A Patel; licensee IJIP. This is an Open Access Research distributed under the terms of the Creative Commons Attribution License (http://creativecommons.org/licenses/by/2.0), which permits unrestricted use, distribution, and reproduction in any Medium, provided the original work is properly cited. 


\section{The tribal population in India, an estimated 87 million, is marked by intense diversity}

Traditionally referred to as advises, tribes, or tribal, scheduled tribes (STs) constitute about 9\% of India's population. Despite diversity in their community history, languages, production practices, and relationships with the non-tribal world, approximately 87 million Indians fall under the advice population, of which nomadic and denitrified communities1 (DNTs), are at a projected 60 million. Nine States - Andhra Pradesh, Chhattisgarh, Gujarat, Jharkhand, Madhya Pradesh, Maharashtra, Orissa, Rajasthan, and West Bengal - together account for more than four-fifths of the total tribal population in India.

Each of the 573 scheduled tribes has their own language, and differs from the one mostly spoken in the State where they reside (Govinda, 2002). Tribal are not a homogenous group. Different tribes, even if living in the same village, maintain exclusive identities. Socialization is generally endogamous and they identify more with people belonging to their tribe rather than to those living in the same village or area.

The current perception of tribal, and their resulting exclusion from mainstream society, can be traced to the pre-Independence period:

In pre-colonial times, nomadic communities sustained themselves through livelihood options such as cattle rearing, trade, crafts, carrying items for barter etc. The advisees of India repeatedly rebelled against the British in the Northeast, Bengal, Bihar, Madhya Pradesh, Maharashtra, Gujarat and Andhra Pradesh. Advice rebellion in hills and forest was concurrent with education of the rest of India (Devy, 2008). Branded as "criminals" during the long period of British rule, the land possessed by the "criminal tribes" was alienated. At the time of independence, India started to view the advisees as primitive, and thus out of step with history (Devy, 2008).

Each of the 573 scheduled tribes has their own language, and differs from the one mostly spoken in the State where they reside (Govinda, 2002). Tribal are not a homogenous group. Different tribes, even if living in the same village, maintain exclusive identities. Socialization is generally endogamous and they identify more with people belonging to their tribe rather than to those living in the same village or area.

1 This is a government assigned category for nomadic communities. Some of these communities are also classified as scheduled castes (SC), scheduled tribes (ST) and other backward classes (OBC), while others are left out entirely.

"The history of tribal during the last 60 years is filled with stories of forced displacement, land alienation and increasing marginalization, eruption of violence and the counter-violence by the State. Going by any parameters of development, the tribal always figure at the tail end. The situation of the communities that have been pastoral or nomadic has been even worse."

Ganesh Devy, Founder, Bhasha

As a result, tribal communities continue to face economic deprivation and lack of access to basic services:

As a basic component of human development, the 83rd Amendment to the constitution has made free elementary education a fundamental right of all the citizens of India. Successive governments have attempted to balance the inequity in the education system, particularly for the 
marginalized groups. Acknowledging that tribal comprise the most deprived and marginalized groups with respect to education, a host of programs and measures have been initiated since India's Independence. With education viewed as a crucial input for total development of tribal communities, elementary education has been made a priority area in the tribal sub-plans since the 5th Five Year Plan

(1974-79). As of March 2001, there were 16 million ST children out of a total child population of about 193 million in the age group of 6-14 years in the country.

"In the 1980s, with literacy levels in the tribal areas 20\% lower than the national average, an ideological shift in government thinking occurred. The realization of the need to mainstream tribal areas was based on the link between lack of education and under-development of tribal areas."

A. M. Tiwari, Secretary, Tribal Development Affairs, Gujarat

There have been marked improvements in access, and to some extent in quality of primary education in tribal areas:

Education has recently witnessed a rapid transformation, particularly in the areas of access, pedagogic reform and community participation in tribal areas. Emphasis has been on improving access to primary education through schemes of non-formal education (NFE), and attempts to improve quality via training, using local teachers, adapting curriculum and providing locally relevant teaching-learning materials to tribal students.

"Fundamental changes in how society thinks are essential to enable the marginalized to engage with the mainstream, and thereby improve their survival (and revival) chances after a disaster. In societies where prejudice and bias run deep and there is little public debate on key issues, the need for a profound shift in attitude is critical."

Suchitra Sheth, Founder of Tribal Education Community, Setu

Low literacy rates continue to indicate a need for more holistic support, from health to non-tribal attitudes, thus allowing for delivery of high-quality education:

Despite the education initiatives, there is disparity among the states in terms of tribal literacy rates ranging from $82 \%$ in Mizoram to $17 \%$ in Andhra Pradesh. The ST literacy rate continues to be below the national average of $29.6 \%$ (Govinda, 2002), with literacy rates among tribal communities (in particular women) tending to be the lowest2. There exist areas in the tribaldominated districts across India that remains largely unnerved by primary education facilities. Tribal children tend to inhabit forests and hard-to-reach areas where dwellings are spread and access to good quality education is more limited. Low enrolment coupled with soaring drop-out rates in primary schools exacerbates the problem, which has its origin in a gamut of inter-related cultural and socio-economic variables. Advises are associated with a certain stigma and behavior, which can be partially tackled through a change in mindset among non-tribal.

The under-development of the tribal areas further exacerbates issues in delivering quality education:

1. Good teachers prefer to live in urban/semi urban centers and therefore, need to commute for 4-5 hours per day to reach tribal area schools 
2. Lack of electricity and water results in poor school infrastructure causing dismal sanitary conditions and low ventilation

3. Long lead times for delivery of teaching materials imply that textbooks and training materials arrive at the schools after the training program, or not at all

\section{PIECES OF THE PUZZLE:}

Reasons for Out-of-School Tribal Children

\section{High numbers for tribal out-of-school children (those never enrolled in school or drop- outs) stems from a range of factors:}

Empirical evidence suggests that tribal children possess the basic cognitive abilities and psychological dispositions for successful participation in schools, and their low achievement levels are attributed to school-related variables as would apply to non-tribal students (Gautam, 2003). Poor performance of tribal students and the below average situation of primary education in tribal areas is driven by inter-related factors. Most children tend to be first generation learners whose education is not reinforced or supported in their home environments. Some of these issues can be addressed through appropriate program design and strategy.

"The situation of tribal education is related to the quality of education in general, and not solely to being tribal. Of course being a tribal also means that most of the time they are also poor, they live in areas where the provision of education is very weak, so the situation is not only because they are tribal but because of all these inter-related issues. It is important therefore to view the problem in all its complexity."

Priyanka Singh, Incharge, Education and Health Programs, Seva Mandir

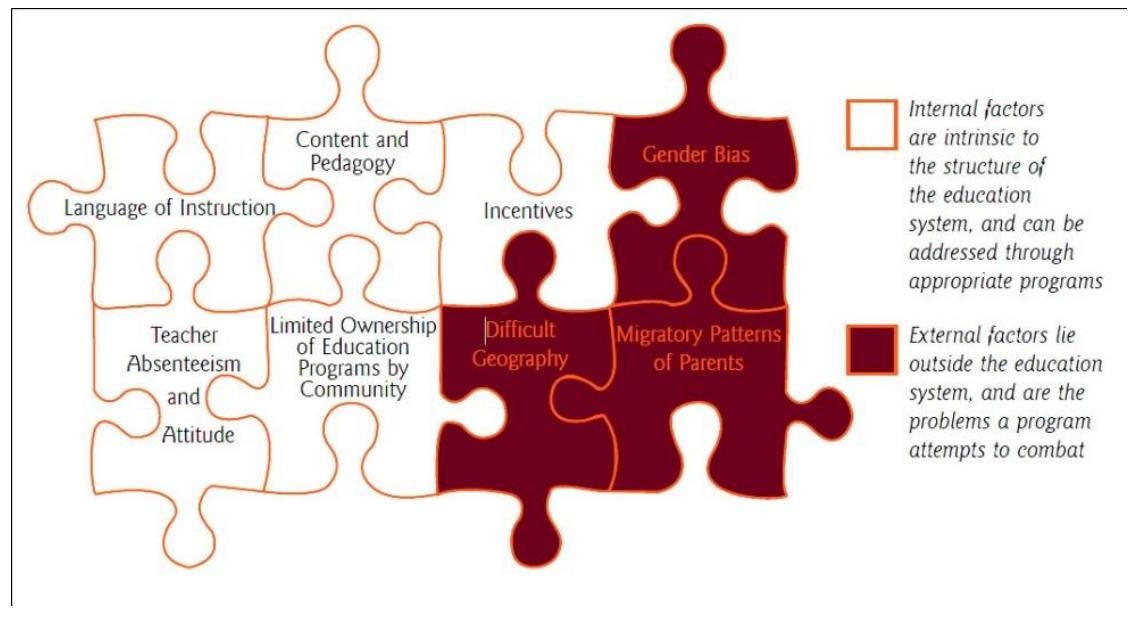




\section{EXTERNAL FACTORS: \\ Gender Bias}

Although external to the education system, gender disparity is an important issue that needs to be tackled via appropriate programs. Tribal girls have a higher tendency to drop-out and a lower tendency to enroll in school.

The Inexcusable Absence of Girls: Gender Disparity in Education:

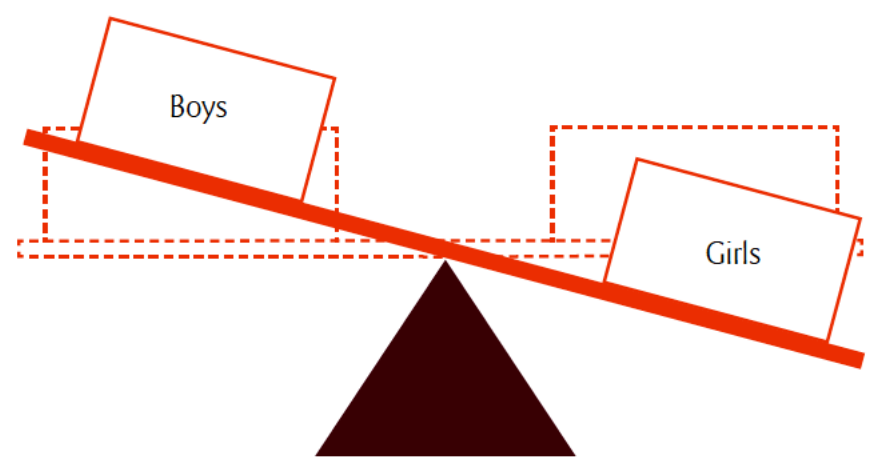

Gender imbalance is entrenched at all levels of education, placing tribal girls at a disadvantage in terms of their overall advancement

Among the tribal community, tribal girls form the most neglected group, and are least likely to be educated. An estimated 37\% of girls aged 7-14 belonging to the lowest castes or tribes do not attend school, compared with $26 \%$ of majority girls of the same age (Lewis and Lockheed, 2007). Tribal girls account for only $18 \%$ of the total girls enrolled at school, and their dropout rate is $67 \%$. Additionally, school attendance for tribal girls is 9 percentage points below that of tribal boys.

Tribal communities are more likely to educate boys than girls due to social and economic factors - exacerbating this inequity

In many tribal communities, parents give minimal importance to girls' education due to economic and social limitations, send them to school only intermittently, or keep the girls sheltered from the outside world. Most frequently, girls, apart from taking part in agricultural activities and collection of forest products are engaged in sibling care. They are often forcibly pulled out from schools, and become child laborers, never to return to education. For example, tribal girls constitute majority of the migrant child labor (primarily tribal girls) working in cotton fields (Rajasekaran, 2008).

\section{INTRODUCTION:}

Many researchers have found that intelligence and academic motivation is one of the factors contributing to the academic achievement of students as such the present study tries to certain whether there is any significant difference in the academic achievement of the pupils' studying in secondary schools. Academic motivation means the ways of studying whether systematically or 


\section{Need For Life Skills Education among Tribal and Non Tribal Students}

unsystematically efficiently or otherwise study can be interpreted as a planned program of subject mastery.

Intelligence cover all related aspects of variable I. Q. and non variable I. Q. other way components of intelligence is understanding, classification, words of opposite, reasoning ability, same relation, number ability, arrangement sentence etc.

Academic motivation cover all related main aspect of attitudes towards school, aspiration of academic and present studying students of study habits. Many researchers say academic motivation and academic achievement is related variables.

We find in intelligence was related to $\mathrm{n}$-ach, socio cultural status, academic achievement (Singh R, 1986, Prakash J, 1986) and self identify (Sahai S. K, 1985) the period under review is not strikingly different from the earlier one (Sinha S. K 1977) reported negative attitude towards the present examination system using a Liker-type questionnaires among university students, teachers and guardians. Kumari Sudha (1982) study was significant difference among the four socio metric groups in case of intelligence and achievement. Mr. Dixit and Mithilesh Kumari (1985) study at all the other intellectuals' levels the academic achievement of the girls was superior to that of the boys. In case of boys there was very high correlation between intelligence test scores and academic achievement.

\section{OBJECTIVES:}

The objectives of the present study are as such...

O.1: To study the academic achievement of tribal and non-tribal students.

O.2: To study the effects of intelligence and academic motivation on the levels of academic achievement.

O.3: To study the interactional effects of intelligence and academic motivation on academic achievement of tribal and non-tribal students.

\section{HYPOTHESES:}

The following null hypothesis is stated for the present investigation...

HO1. There is no significant effect of intelligence on the levels of academic achievement of tribal and non-tribal students.

HO2. There is no significant effect of academic motivation on the level of academic achievement of tribal and non-tribal students.

HO3. There is no significant effect of the main difference of academic achievement of tribal and non-tribal students. 
HO4. There is no significant interactional effect of I. Q. X case on the academic achievement of tribal and non-tribal students.

HO5. There is no significant interactional effect of academic motivation $\mathrm{X}$ case on the academic achievement of non-tribal students.

\section{DESIGN OF RESEARCH:}

In this study 7 tribal and non tribal high secondary schools covering $50 \%$ of the total population from the total number of 12 schools located in PANCHMAHALS district (Gujarat-India) were selected on random basis all the students both tribal and non tribal studying in $\mathrm{X}$ standard were Desai variable -non variable group intelligence test. Researcher developed a test of academic motivation were administered this study. Thus the sample included 350 tribal and 350 non tribal students.

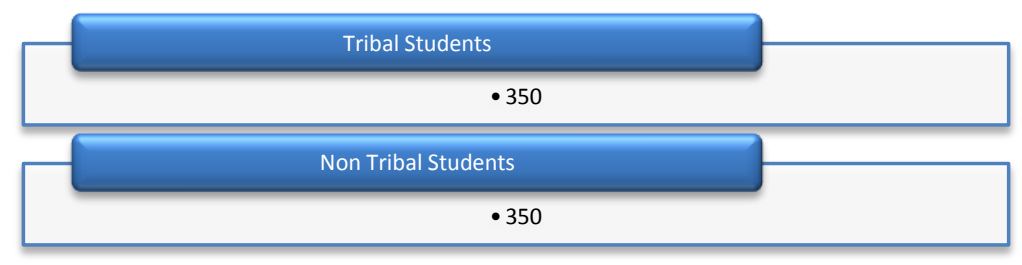

Total Sample for this study is 700 .

\section{TOOLS:}

In the present study for finding of the affects I. Q. and academic motivation on the academic achievement the main objectives of this study. Researcher has developed Education Progress Report of research sample variable of educational achievement is tool of school preliminary examination in March 2009. Percentage score present study is for finding out the I. Q. and academic motivation of students of class X. The IQ test developed by Mr. K. G Desai has been used. The test consists of 80 items classified into eight test battery, classified into eight categories viz. understanding, classification, words of opposite, reasoning ability, same relation number ability, unarranged sentence etc. The test includes some items which discriminate students at 0.01 levels and 0.05 levels. Some items into inventory are of diagnostic nature.

The academic motivation test developed by researcher has been used the test consist of 120 items classified into three sub. Inventory of 40 items classified into three categories viz. attitudes towards schools, academic aspiration and study habits. Each item in the inventory is to be tricked by students against "agree", "partly agree", 'disagree". The respondent is required to tick only one choice against those three choices which we think is best applicable to his/her. In case of the sub variables depicting goods academic motivation, the students has to be given three marks if he put, a tick in the column of three, two, one marks are to be given if he puts a trick mark in the column of agree, partly agree, disagree. In the case of statements depicting bad academic 
motivation, the academic motivation test score is between 120 to 360 in positive and negative items, high scores on the inventory will indicate good academic motivation and vice versa.

\section{DATA:}

The data collected were of quantitative nature in the form of score of IQ. Academic motivation and academic achievement of the pupils of standard X.

\section{ANALYSIS FORMULA:}

The sample of this study is taken from selected 12 schools. It was observed that one school a co education school had results which were consistently superior to the results of the others 7 schools. It was named better high achieving school having 350 tribal and 350 non tribal students.

For analysis formula used is CR value, t- Test, F- Test.

\section{RESULTS:}

Table: 1, Relation Academic Achievement of tribal and non tribal students.

\begin{tabular}{|c|c|c|c|c|c|c|}
\hline $\begin{array}{c}\text { Group of } \\
\text { sample }\end{array}$ & $\mathbf{N}$ & Mean & MD & SD & $\begin{array}{c}\text { CR } \\
\text { Value }\end{array}$ & $\begin{array}{c}\text { Levels of } \\
\text { Significance }\end{array}$ \\
\hline $\begin{array}{c}\text { Tribal } \\
\text { students }\end{array}$ & 350 & 44.00 & 42.3 & 10.15 & 4.97 & $\begin{array}{c}\text { Sign } \\
0.01 \\
\text { level }\end{array}$ \\
\hline $\begin{array}{c}\text { Non tribal } \\
\text { students }\end{array}$ & 350 & 48.72 & 42.3 & 11.092 & & \\
\hline
\end{tabular}

Table: 2, The Score of IQ and Academic Achievement of the high, medium, low between tribal and non tribal students.

\begin{tabular}{|c|c|c|c|c|c|c|c|c|c|c|c|c|c|}
\hline \multirow{3}{*}{$\begin{array}{c}\text { Variable } \\
\quad \downarrow\end{array}$} & \multirow{3}{*}{$\begin{array}{l}\text { Level of } \rightarrow \\
\text { Academic } \\
\text { Achievement }\end{array}$} & \multicolumn{4}{|c|}{ High } & \multicolumn{4}{|c|}{ Medium } & \multicolumn{4}{|c|}{ Low } \\
\hline & & \multicolumn{4}{|c|}{55 to 70} & \multicolumn{4}{|c|}{40 to 54} & \multicolumn{4}{|c|}{ Below 39} \\
\hline & & $\mathbf{N}$ & $\mathbf{M}$ & 6 & 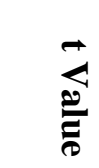 & $\mathbf{N}$ & $\mathbf{M}$ & 6 & 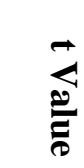 & $\mathbf{N}$ & $\mathbf{M}$ & 6 & 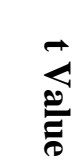 \\
\hline 1 & 2 & 3 & 4 & 5 & 6 & 7 & 8 & 9 & 10 & 11 & 12 & 13 & 14 \\
\hline \multirow{2}{*}{$\begin{array}{l}\text { IQ } \\
\text { and } \\
\text { caste }\end{array}$} & Tribal & 36 & 120.7 & 14.7 & \multirow{2}{*}{ *) } & 166 & 115.6 & 13.4 & \multirow{2}{*}{ * } & 48 & 90.5 & 17.5 & \multirow[t]{2}{*}{ * } \\
\hline & Non tribal & 48 & 125.1 & 16.5 & & 170 & 118.5 & 14.7 & & 42 & 92.6 & 15.2 & \\
\hline \multirow{2}{*}{$\begin{array}{l}\text { Academic } \\
\text { motivatio } \\
\mathrm{n} \text { and } \\
\text { Caste }\end{array}$} & Tribal & 36 & 321.7 & 10.3 & \multirow{2}{*}{ * } & 166 & 308.1 & 13.4 & \multirow{2}{*}{ * } & 48 & 312.7 & 11.7 & \multirow{2}{*}{$* \stackrel{N}{\stackrel{N}{v}}$} \\
\hline & Non tribal & 48 & 310.3 & 12.7 & & 170 & 303.7 & 12.4 & & 42 & 306.4 & 13.6 & \\
\hline
\end{tabular}

* Non Significant at 0.05 levels, $* *$ Significant at 0.05 or 0.01 levels 
Table: 3, the score of factorial design analysis of variance of the effect of caste (Tribal- Non Tribal) X I. Q.

A- Intelligence Quotient

\begin{tabular}{|c|c|c|c|c|}
\hline Caste & High & $\begin{array}{c}\text { Medium } \\
\text { A2B2 }\end{array}$ & $\begin{array}{c}\text { Low } \\
\text { A3B3 }\end{array}$ \\
\hline \multirow{3}{*}{$\begin{array}{c}\text { Tribal } \\
\text { Students }\end{array}$} & $\mathrm{N}$ & 20 & 120 & 45 \\
\cline { 2 - 5 } & $\mathrm{Ex}$ & 1210 & 3544 & 3474 \\
\cline { 2 - 5 } & $-\mathrm{X}$ & 60.5 & 46.2 & 38.6 \\
\cline { 2 - 5 } & $\mathrm{Ex}^{2}$ & 462101 & 483118 & 320138 \\
\hline \multirow{2}{*}{$\begin{array}{c}\text { Non- Tribal } \\
\text { Students }\end{array}$} & $\mathrm{N}$ & 46 & 150 & 74 \\
\cline { 2 - 5 } & $\mathrm{Ex}$ & 2700 & 7514 & 3084 \\
\cline { 2 - 5 } & $-\mathrm{X}$ & 58.7 & 50.1 & 41.7 \\
\cline { 2 - 5 } & $\mathrm{Ex}^{2}$ & 420640 & 397120 & 362898 \\
\hline
\end{tabular}

B- Academic Motivation

\begin{tabular}{|c|c|c|c|c|}
\hline Caste & & $\begin{array}{c}\text { High } \\
\text { A1B1 }\end{array}$ & $\begin{array}{c}\text { Medium } \\
\text { A2B2 }\end{array}$ & $\begin{array}{c}\text { Low } \\
\text { A3B3 }\end{array}$ \\
\hline \multirow{3}{*}{$\begin{array}{c}\text { Tribal } \\
\text { Students }\end{array}$} & $\mathrm{N}$ & 32 & 146 & 64 \\
\cline { 2 - 5 } & $\mathrm{Ex}$ & 1786 & 6496 & 3244 \\
\cline { 2 - 5 } & $-\mathrm{X}$ & 55.8 & 44.5 & 50.7 \\
\cline { 2 - 5 } & $\mathrm{Ex}^{2}$ & 366718 & 427114 & 66994 \\
\hline \multirow{3}{*}{$\begin{array}{c}\text { Non- Tribal } \\
\text { Students }\end{array}$} & $\mathrm{N}$ & 34 & 124 & 100 \\
\cline { 2 - 5 } & $\mathrm{Ex}$ & 2064 & 3246 & 4380 \\
\cline { 2 - 5 } & $-\mathrm{X}$ & 70.7 & 42.3 & 43.8 \\
\cline { 2 - 5 } & $\mathrm{Ex}^{2}$ & 380116 & 336894 & 65552 \\
\hline
\end{tabular}

Table: 4

\section{Significant of $F$ value}

\begin{tabular}{|c|c|c|c|c|c|c|}
\hline $\begin{array}{c}\text { Interactional } \\
\text { Variable }\end{array}$ & Origin of & DF & SS & MS & $\begin{array}{c}\text { F } \\
\text { Value }\end{array}$ & $\begin{array}{l}\text { Significant } \\
\text { of } \mathbf{F}\end{array}$ \\
\hline 1 & 2 & 3 & 4 & 5 & 6 & 7 \\
\hline \multirow[t]{5}{*}{$\begin{array}{l}\text { Caste X } \\
\text { I. Q. }\end{array}$} & $\begin{array}{l}\text { *Independent } \\
\text { Variable- } 1 \\
\text { I.Q }\end{array}$ & 1 & 122.72 & 122.72 & 0.039 & $\begin{array}{l}\text { Not } \\
\text { Significant } \\
\text { at } 0.05 \\
\text { levels }\end{array}$ \\
\hline & $\begin{array}{l}\text { *Independent } \\
\text { Variable- } 2 \\
\text { Caste }\end{array}$ & 2 & 10424.23 & 10424.23 & 3.35 & $\begin{array}{l}\text { Significant } \\
\text { at } 0.05 \\
\text { levels }\end{array}$ \\
\hline & *I.Q & 2 & 260.15 & 130.075 & 0.042 & $\begin{array}{l}\text { Not } \\
\text { Significant } \\
\text { at } 0.05 \\
\text { levels }\end{array}$ \\
\hline & X Caste & & & & & \\
\hline & *error & 488 & 759567.26 & 3117.9 & & \\
\hline
\end{tabular}


Need For Life Skills Education among Tribal and Non Tribal Students

\begin{tabular}{|c|c|c|c|c|c|c|}
\hline \multirow[t]{5}{*}{$\begin{array}{l}\text { Caste X } \\
\text { Academic } \\
\text { Motivation }\end{array}$} & $\begin{array}{l}\text { *Independent } \\
\text { Variable- } 1 \\
\text { Academic } \\
\text { Motivation }\end{array}$ & 1 & 86.96 & 86.96 & 0.0777 & $\begin{array}{l}\text { Not } \\
\text { Significant } \\
\text { at } 0.05 \\
\text { levels }\end{array}$ \\
\hline & $\begin{array}{l}\text { *Independent } \\
\text { Variable- } 2 \\
\text { Caste } \\
\end{array}$ & 2 & 7671.4 & 3835.7 & 3.02 & $\begin{array}{l}\text { Significant } \\
\text { at } 0.05 \\
\text { levels }\end{array}$ \\
\hline & $\begin{array}{l}\text { *Academic } \\
\text { Motivation }\end{array}$ & 2 & 534.39 & 267.2 & 0.24 & $\begin{array}{l}\text { Not } \\
\text { Significant } \\
\text { at } 0.05 \\
\text { levels }\end{array}$ \\
\hline & $\mathrm{X}$ caste & & & & & \\
\hline & *error & 488 & 275584.5 & 1129.4 & & \\
\hline
\end{tabular}

\section{CHARTS:}

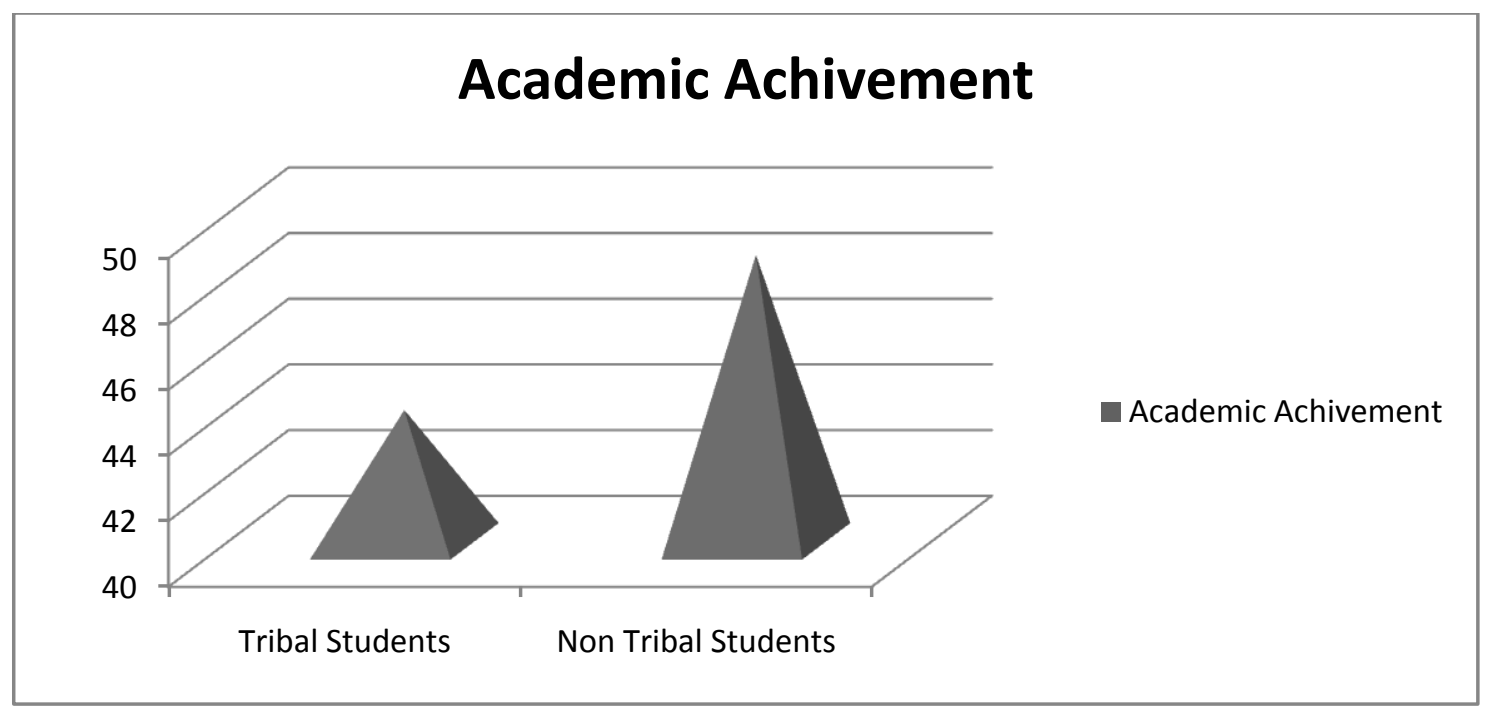

\section{INTERPRETATION OF TABLES AND TESTING OF HYPOTHESIS:}

The study of table- 1 show that t- value is significant at 0.01 levels constructed by research $\mathbf{H O 3}$ is "There is no significant of the mean difference of Academic Achievement of tribal and nontribal students" tested t-value is 4.97 which is significant. If we reject of there is significant of the mean difference of Academic Achievement between Tribal and non Tribal students.

HO1: "There is no significant effect of intelligence on the levels of academic achievement between tribal and non tribal students" tested-t value is 10.29, 11.74, 0.57 (I.Q. High, Medium Academic Achievement of the tribal and non tribal students) which is significant if we reject of this null hypothesis, but I.Q. of low Academic Achievement of the Tribal and non Tribal students which is not significant. So we accept of this null hypothesis. 
HO4: "There is no significant interactional effect of I.Q. X caste on the Academic Achievement of tribal and non tribal student" tested F. value is 0.042 which is not significant. So, we accept of no significant interactional effects of I.Q. X caste on the Academic Achievement of tribal and non-tribal students.

HO5: "There is no significant interactional effect of Academic Motivation $X$ caste on the Academic Achievement of tribal and non tribal students" tested F- value is 0.24 which I not significant. So, we accept of no significant interactional effects Academic Motivation X caste on the Academic Achievement of Tribal and non Tribal students.

HO2: "There is no significant effect of Academic Motivation on the levels of Academic Achievement of tribal and non tribal students" tested t-value is 4.54, 3.14, 2.15 (Academic Motivation of high, medium, low Academic Achievement of the Tribal and non Tribal students) which is significant at 0.05 or 0.01 levels. So, we reject of this null hypothesis.

\section{FINDING:}

- There is significant effect of intelligence on the level (High, Medium Academic Achievement) of the academic achievement between tribal and non tribal students.

- There is significant effect of Academic Motivation on the levels of the academic achievement between tribal and non tribal students.

- There is significant of the mean difference of academic achievement of tribal and non tribal students.

- There is no significant interactional effect of I.Q. caste on the academic achievement of tribal and non tribal students.

- There is no significant interactional effect of Academic Motivation X caste on the Academic Achievement of tribal and non tribal students.

\section{REFERENCE:}

1. Aggrawal J. C. "Educational Research” Arya Book Depot, Delhi 1975, Page. 15 to 20

2. Anastasi Anne. "Psychological Measurement Macmillan" Robants Publication, New York, 1961

3. Asthasan Bipin. "Measure \& Evaluation in Psychology" Vinod Pustak Mandir, Agra, 2000, Page. 22 to 25

4. Best Jhon W. "Research in Education" Delhi Prentice Hall of India, 1977

5. Besunont, Henry. "Psychological Factor in Education" MCC Raw Hill Book, Company INC First Edition, 1949, Page. 45 and 46

6. Desai K. G. "Education of Psychology" Anada Book Publication, Ahmadabad, 1999, Page. 33 to 35

7. Garret H. E, "Statistics in psychology and Education" Vakils Feher and Simons, Bombay, 1973 
8. Gautam, V. 2003. "Education of Tribal Children in India and the Issue of Medium of Instruction: A Janshala Experience.” UN/ Government Janshala Programme. New Delhi.

9. Govinda, R. 2002. India Education Report: A Profile of Basic Education. Oxford University Press.

10. Jha, J and D. Jhingran. 2002. "Review of Elementary Education for Poorest and Other Disadvantaged Groups: The Real Challenge of Universalisation." Centre for Policy Research. New Delhi.

11. Jhingran, D. 2000. "Janshala - Mainstreaming Out of School Children through Bridge Courses". Monthly Newsletter of the Joint GOI-UN System Education Program. AprilJune.

12. Kothai, K. 2007. "Seasonal Migration hinders Education in India". OneWorld South Asia. October.

13. Mishra, M. 2007. "Status of Elementary Education in Tribal Areas of Orissa". Department of Tribal Education, Orissa.

14. Mishra, R.C., Sinha, D and J.W. Berry. 1996. Ecology, Acculturation and Psychological Adaptation: A Study of Adivasis in Bihar. International Association for Cross-Cultural Psychology.

15. Nair, P. 2007. "Whose Public Action? Analyzing Inter-sectoral Collaboration for Service Delivery: Identification of Programmes for Study in India.” International Development Department, Economic and Social Research Council. February.

16. National Tribal Commission. 2008. "Education of Tribal People in India." March.

17. Noronha, A. 2006. "Education of Tribal Children, from Social Mobilization to Poverty Alleviation." OneWorld South Asia. March.

18. Rajasekaran, G. 2008. "Tribal girls till the land in Bt cotton fields." Newindiapress.com.

19. Sarva Shiksha Abhiyan. 2002. "Education of Tribal Children in India."

20. Stephen Wisemer. "Intelligence and Ability" Pengin Book.Ltd, England, 1961

21. Sweta Bagai, Neera Nundy. "Tribal Education" DASRA, 2009

22. UNESCO. 2002. "Innovations in Non-Formal Education: A Review of Selected Initiatives from the Asia-Pacific Region.” Bangkok. 